\title{
RESEARCH INSTRUMENTS: A QUESTIONNAIRE AND AN INTERVIEW GUIDE USED TO INVESTIGATE THE IMPLEMENTATION OF HIGHER EDUCATION OBJECTIVES AND THE ATTAINMENT OF CAMEROON'S VISION 2035
}

\author{
Awu Isaac Oben ${ }^{\mathrm{i}}$ \\ Faculty of Education, \\ Southwest University, \\ Chongqing, China
}

\begin{abstract}
:
This paper is an excerpt from a Master Degree Thesis (M.Ed.) conducted in 2016. The aim is to present a systematic and detailed explanation of the construction and administration of two research instruments (a questionnaire and an interview guide) used for data collection in the study "The Implementation of Higher Education Objectives and the Attainment of Cameroon's Vision 2035". This information will serve as a useful guide to the researchers working in the same or similar research project at various context, to adapt or adopt the various items in these instruments when and wherever necessary. The questionnaire (44 items) and interview guide used in the aforementioned study were subjected to Validity and reliability. To give a clear picture of the context and nature of the aforementioned research, the researcher included some related sections from the original research which led to (guided) the construction of the research instruments. These sections include; statement of the problem, objectives of the study, research questions, research design, instrumentation, questionnaire for students, validation of the instrument (face and content), reliability of the instrument, administration of instruments, and procedure for data analysis. A step-by-step (systematic) reading of the aforementioned sections will guide readers to understand why and how the research instruments were selected and constructed. Based on previous studies and related literature, the researcher concluded that a questionnaire and an interview guide were appropriate instruments for the aforementioned study.
\end{abstract}

Keywords: research instruments; questionnaire; interview guide; higher education objectives; Cameroon's Vision 2035

${ }^{i}$ Correspondence: email isaacoben87@gmail.com 


\section{Introduction}

A research instrument is a scientific and systematic designed tool used to collect, measure, and analyze data related to research interests and alignment(s). Researchers usually need to decide the instrument to use based on the type of study they are conducting: quantitative, qualitative, or mixed-method (i.e. research alignments). Types of instruments may include but not limited to; surveys, tests, questionnaires, achievement/aptitude tests, interviews, scales (measuring and weighing tapes), archival documents and government sources, oral histories, focus group discussion and experiment, observation forms, tally sheets, etc. Each of the instruments has its merits and demerits. The questionnaire is the commonly used instrument for collecting research data from the participants of a study. For this reason, the main research instrument used in the aforementioned study was the questionnaire, followed by an interview guide. Though the original aim of this paper is to present the two research instruments (a questionnaire and an Interview guide) used for data collation in the study "The Implementation of Higher Education Objectives and the Attainment of Cameroon's Vision 2035". It is important to include some relevant sections from the original research, such that readers will systematically follow and understand why each decision was made. For this reason, the following sections have been included, namely; statement of the problem, objectives of the study, research questions, research design, instrumentation, questionnaire for students, validation of the instrument (face and content), reliability of the instrument, administration of instruments, and procedure for data analysis.

\subsection{Statement of the Problem}

The anticipated dream of 2009 to transform Cameroon into an emerging, a democratic and united country in diversity by the year 2035, and Article 2 of Law No. 005 of 16 April 2001, to guide Higher Education (HE) in Cameroon which stated that "the HE realm shall be assigned a basic mission of producing, organizing and disseminating scientific, cultural, professional and ethical knowledge for development purposes" (MINESUP, 2001) appears more theoretical and less practical. This is because the aforementioned strategic expectations have achieved almost an insignificant percentage since its formulation. This has come to create and heighten arguments over the relationship between the implementation of Higher Education Objectives (HEO) and Cameroon's Vision 2035. Despite the increase in the level of professional education with thousands of graduates each year from Higher Institutes of Learning there seems to be no significant increase in the nation's development (low rates of returns in Cameroon's HE). The wide gap that exists in the area of professionalism, poverty alleviation, bilingualism, gender equality, research, industrialization, and national unity just to name a few do not reflect the HEO, hence a call for urgent concern. 
HEO calls for the distinguished acquisition of quality skills, knowledge, and attitude by its graduates, yet the link seems to be farfetched. The problem with HEO seems to lie in its implementation such as the teaching-learning process. The issue of effective implementation of HEO remains questionable, based on its product (graduates) who appear less productive and dependable. Experience has shown that most graduates from HE are less productive and have little to offer to the nation's development compared to the expected results. This happens probably because they lack the required skills, knowledge and attitude. Consequently, a significant percentage of graduates constitute a high dependency ratio. This challenge has at stake the teaching-learning process via the implementation of HEO. Hence the great need to examine to what extent the implementation of HEO predicts Vision 2035.

The problem that led to this study emanated from the fact that much is not known about the direct relationship and extent of the implementation of $\mathrm{HEO}$ and the attainment of Vision 2035 because of little or no monitoring. Yet in Section 3 of Law No.005 of 16 April, 2001Article 10: (1) aims at permanently monitoring the implementation of rules and regulations in all HE domains as well as academic and pedagogic activities of all the educational institutions and punish defaulters. It is as a result of little efforts employed in research and monitoring of this relationship since 2001 that provoked the researcher to investigate the relationship that exists between the implementation of HEO and the attainment of Cameroon's Vision 2035.

\subsection{Objective of the Study}

The purpose of this study was to investigate the level implementation of Higher Education Objectives (HEO) on the attainment of Cameroon's Vision 2035 with respect to poverty alleviation, and national unity and consolidation of democracy.

\subsubsection{Specific Objectives of the Study}

Based on the aforementioned purpose, this study sorted to specifically address the following objectives;

1) To find out whether the promotion of ethics and national consciousness is effectively facilitating the attainment of Cameroon's Vision 2035 with respect to poverty alleviation, and national unity and consolidation of democracy.

2) To find out whether the promotion of bilingualism is effectively ensuring the attainment of Cameroon's Vision 2035 with respect to poverty alleviation, and national unity and consolidation of democracy.

3) To find out whether the strengthening of gender equality is effectively ensuring the attainment of Cameroon's Vision 2035 with respect to poverty alleviation and national unity and consolidation of democracy.

4) To find out whether the training of trainers and researchers is effectively ensuring the attainment of Cameroon's Vision 2035 with respect to poverty alleviation and national unity and consolidation of democracy. 


\subsection{Research Questions}

To what extent does the implementation of HEO ensure the attainment of Cameroon's Vision 2035 with respect to poverty alleviation, and national unity and consolidation of democracy?

\subsubsection{Specific Research Questions}

1) To what extent does the promotion of ethics and national consciousness facilitate the attainment of Cameroons vision 2035 with respect to poverty alleviation, and national unity and consolidation of democracy?

2) To what extent does the promotion of bilingualism ensure the attainment of Cameroons vision 2035 with respect to poverty alleviation, and national unity and consolidation of democracy?

3) To what extent does the strengthening of gender equality ensure the attainment of Cameroons vision 2035 with respect to poverty alleviation, and national unity and consolidation of democracy?

4) To what extent does the training of trainers and researchers ensure the attainment of Cameroons vision 2035 with respect to poverty alleviation, and national unity and consolidation of democracy?

\section{Research Design}

According to Amin (2005) research design is the conceptual structure within which the quantitative or qualitative research is conducted and constitutes the blueprint for the measurement of variables, collection of data and analysis. It helps the researcher to answer questions like, what is the study about? Where will the study be carried out? What type of data is required? There are many types of research designs. The design which is employed for this study is the survey. According to Amin (2005) Survey research involves the collection of information from sample individuals through their responses to questions. Similarly, Mbua (2003, p.521) stated that survey research design can be defined as "the collection of data from a defined population to describe the variables or issues under study". In a survey research design a group of people or items are studied by collecting and analyzing data from only a few or items considered to be representative of the entire group and also specifies how such data will be collected and analyzed. It employs a variety of data gathering instruments or techniques such as questionnaires and test (Nworgu, 1978).

The survey is the most appropriate for this study because it is able to extract data that are near to the exact attribute of the larger population (population of the study). It is also low cost and convenient data gathering, and ideal for scientific research since it provides all the participants with a standardized stimulus. 


\subsection{Instrumentation}

The researcher made use of a questionnaire and an interview guide as instruments for data collection. A questionnaire is a behavioral/psychological measuring instrument designed to collect qualitative information from members of a population which can then later be transformed into quantitative or numerical data for analysis (Amin, 2005). A set of questionnaires designed for students was given to the respondents to answer. They were developed to address the specific objectives of the study. Questionnaires are found appropriate in enabling the researcher gather a large amount of data from many subjects economically (Amin, 2009). Questionnaires were advantageous because they save time on the part of the researcher and heighten the independence and accuracy of responses from respondents.

\subsection{Questionnaire for Students}

It began with a cover letter which aimed at introducing the researcher, aim of the exercise and to motivate the respondents. It consisted of 7 sections, where section A: Demographic information (2 items), section B: Promotion of ethics and national consciousness, section C: Promotion of bilingualism (8 items), section D: Strengthening of gender equality (8 items), section E: The training of trainers and researchers (8 items), section F: poverty alleviation (6 items), and section G: Strengthening of national unity and consolidation of democracy (6 items). All the aforementioned were made up of closed ended opinion statements with a total of forty four (44) items. All the opinion statements were rated on a 4-point Likert-type scale ranging from "Strongly Agree" (SA), "Agree" (A), "Disagree" (D), to "Strongly Disagree" (DA).

The interview guide was constructed with questions based on the research questions to find out from teachers the relationship of the research variables. It consisted of 7 sections, where section A: Demographic information (2 items), section B: Promotion of ethics and national consciousness, section C: Promotion of bilingualism (2 items), section D: Strengthening of gender equality ( 2 items), section E: The training of trainers and researchers (2 items), section F: Poverty Alleviation (2 items), and section G: Strengthening of national unity and consolidation of democracy ( 2 items).

\subsection{Validation of the Instrument (Face and Content)}

Validity refers to the degree to which an instrument measure what it is set out to measure. According to Amin (2005), validity refers to the ability to produce accurate results and the degree to which an instrument measures what it is supposed to measure. In addition Amin (2005) maintained that, validity refers to the ability to produce accurate results and the degree to which an instrument measures what it is supposed to measure. The instrument was subjected to the face and content validity.

To ensure face validity of the instrument, the researcher gave the draft copy of the questionnaire and interview guide to 8 course mates for peer review and to 2 language teachers to ensure that the items were easy to read, constructed with simple language, 
presentable and appealing to the respondents and make the necessary corrections and suggestions on grammar and organization of the questions. The corrections were made for language appropriateness and clarity and then considered valid to obtain useful information relevant for the attainment of the objectives of the study. Finally the questionnaire and interview guide used were corrected, re-constructed and submitted to the supervisor for final correction, and approval.

To evaluate content validity of the instrument, the researcher with the help of the supervisor and statistician edited it, checked the relevance of items to the objectives of the study. This was confirmed by the researcher's supervisor. The instrument was passed on to an expert in Educational Measurement and Evaluation. The validity indices were calculated for each of the items and for the whole instrument, to ensure that the instrument was valid enough to be used for the study. The results showed that the validity indices ranged between 0.74 and 0.94 for the items and 0.88 for the whole instrument. These results implied that the instrument was valid enough to be used for the study.

\subsection{Reliability of Instrument}

Reliability refers to a measure of the degree to which a research instrument yields consistent results or data after repeated trials (Amin, 2005). To ensure that, the instrument measures consistently what it was designed to measure, the instrument was trial-tested (pilot study) in one of the Higher Institute of Learning (HIL) in a sub division that was not sampled for the study but which constituted the target population. The researcher with the aid of research assistance administered 30 questionnaires to students and interviewed 2 teachers (male and female). Split half method of assessing reliability was used to test for the reliability of the data. Split half technique, according to Kothari (1985), requires only one testing session thereby eliminating the chance error due to differing conditions and also to eliminate the possibility of not meeting the same previous respondents. In this method, one measuring instrument is given to a group once. At the point of scoring, the measuring instrument is then split into two equivalent halves. Therefore each person in the group is scored on each of the two halves of the measuring instrument, thus resulting in the two sets of scores for each individual. At the end of scoring, two sets of scores are produced and the two sets of scores separated into odd and even numbers were then correlated and the Spearman Brown Prophecy formula was applied which gave an estimated value of 0.89. Since 0.89 according to Amin (2005) indicates an acceptable reliability coefficient, the coefficient of all sections was found to be reliable hence the profound conclusion that the instrument used in the study for data collection tool was reliable.

\subsection{Administration of Instruments}

An authorization letter was obtained from the Head of Department (HOD) of Curriculum Studies and Teaching in the Faculty of Education, University of Buea. It was used to 
access the 14 HIL to administer the questionnaires to students and interview teachers. The researcher met the school authorities of schools for permission to administer the instruments.

The researcher employed the services of two research assistants. The assistants were trained on how to administer and collect data as well as the appropriate behavior required. A daily plan of activities was drawn and the researcher and the assistants visited at least 2 HIL a day. The researcher and the assistants guided the respondents and personally administered the instruments to them face to face to ensure consistency and avoid errors. The researcher and assistants waited and collected the completed questionnaires from respondents. However, since all the respondents could not finish at the time of administration their phone numbers were collected for further follow up when completed such that it ensured a favorable returned rate.

\subsection{Procedure for Data Analysis}

Descriptive and inferential statistics were used for data analysis. The statistical tool used for analysis was the Pearson Product Correlation Moment Analysis (PPMCA). This is because data was collected using the Likert scale; consequently the scale gave continuous data. The independent (implementation of HEO) and dependent (the attainment of Cameroon's Vision 2035) variables gave continuous data. Likert scale data were analyzed at the interval measurement scale which gives continuous data. The formula using deviation from the mean method was;

$$
\Gamma_{\mathrm{xy}}=\frac{\sum(x-\bar{x})(y-\bar{y})}{\sqrt{\sum(x-\bar{x})^{2} \sum(y-\bar{y})^{2}}}
$$

Where,

$\mathrm{x}$ is the independent variable,

$\mathrm{y}$ is the dependent variable and

$\Gamma_{\mathrm{xy}}$ is the correlation coefficient for $\mathrm{x}$ and $\mathrm{y}$.

\subsection{Questionnaire for Students}

Dear Respondent,

I am student in the Department of Curriculum Studies and Teaching (CST) in the University of Buea, with Matriculation Number ED14P018. I am carrying out a research for a Masters of Education (M.Ed.) Thesis entitled, "The Implementation of Higher Education Objectives and the Attainment of Cameroon's Vision 2035". Your response(s) and information to the questions below will be strictly for this research/academic purpose. As such the information will be treated with confidentiality / privacy. I therefore plead for your clear and sincere responses.

Thanks for your understanding and cooperation.

Yours Sincerely

Awu Isaac Oben 
Section A: Demographic Information

Instruction: Please fill and tick $(\sqrt{ })$ appropriate response(s) in the spaces and boxes provided below.

Institution:

Gender:

a) Male

b) Female

Please remember that: Strongly Agree (SA), Agree (A), Disagree (D), Strongly Disagree (SD) in the statements below.

Section B: Promotion of Ethics and National Consciousness

\begin{tabular}{|c|c|c|c|c|c|}
\hline $\mathrm{S} / \mathrm{N}$ & Opinion & SA & A & D & SD \\
\hline 1 & Ethics is given the same weighting $\backslash$ value as other major courses & & & & \\
\hline 2 & In my institution students are taught the Cameroon Constitution & & & & \\
\hline 3 & Students are taught the Traditional African values & & & & \\
\hline 4 & Students are taught the positive and negative aspects of Nation Building & & & & \\
\hline 5 & In my school a student cannot graduate without validating Ethics & & & & \\
\hline 6 & $\begin{array}{l}\text { In my institution Students are taught the aspects of cultural diversities of } \\
\text { Cameroon }\end{array}$ & & & & \\
\hline 7 & Our teachers usually modifies the behavior of students in class & & & & \\
\hline 8 & In my institution Students are taught the National Symbols of Cameroon & & & & \\
\hline
\end{tabular}

Section C: The Promotion of Bilingualism

\begin{tabular}{|c|c|c|c|c|c|}
\hline $\mathbf{S} / \mathbf{N}$ & Opinion & SA & A & $\mathbf{D}$ & SD \\
\hline 9 & $\begin{array}{l}\text { In my institution Students are taught basic communication skills in both } \\
\text { the English and French languages. }\end{array}$ & & & & \\
\hline 10 & $\begin{array}{l}\text { Students in my institution are required to validate the general course (s) } \\
\text { in English language before graduating }\end{array}$ & & & & \\
\hline 11 & $\begin{array}{l}\text { Before graduation Students in my institution are required to validate the } \\
\text { general course(s) in French language }\end{array}$ & & & & \\
\hline 12 & $\begin{array}{l}\text { Students in my institution usually participate in the activities of the } \\
\text { National Bilingualism Day }\end{array}$ & & & & \\
\hline 13 & Instructors in my institution can communicate in both languages & & & & \\
\hline 14 & $\begin{array}{l}\text { Students are evaluated orally and written in the compulsory English and } \\
\text { French language courses. }\end{array}$ & & & & \\
\hline 15 & $\begin{array}{l}\text { The school library is equipped with the same number of books in both } \\
\text { English and French language. }\end{array}$ & & & & \\
\hline 16 & $\begin{array}{l}\text { My performance in the compulsory French language course(s) reflects my } \\
\text { written/verbal skills of communication }\end{array}$ & & & & \\
\hline
\end{tabular}




\begin{tabular}{|c|c|c|c|c|c|}
\hline & & & & & \\
\hline $\mathrm{S} / \mathrm{N}$ & Opinion & SA & A & D & SD \\
\hline 17 & $\begin{array}{l}\text { My institution usually take into consideration Gender Equality when } \\
\text { admitting students }\end{array}$ & & & & \\
\hline 18 & There are more male than female students in the Economics Department & & & & \\
\hline 19 & $\begin{array}{l}\text { In my institution, there are more male than female students in the Science } \\
\text { Departments }\end{array}$ & & & & \\
\hline 20 & $\begin{array}{l}\text { Our teachers usually give high tasks to male than female students during } \\
\text { instruction. }\end{array}$ & & & & \\
\hline 21 & Male instructors usually favor female students in class & & & & \\
\hline 22 & $\begin{array}{l}\text { There is Gender Equality in the numerical strength of teaching staff in my } \\
\text { institution }\end{array}$ & & & & \\
\hline 23 & $\begin{array}{l}\text { A majority of students in my institution prefer male to female students for } \\
\text { student leadership }\end{array}$ & & & & \\
\hline 24 & Female students are usually excluded in some school activities & & & & \\
\hline
\end{tabular}

Section E: The Training of Trainers and Researchers

\begin{tabular}{|c|c|c|c|c|c|}
\hline $\mathrm{S} / \mathbf{N}$ & Opinion & SA & A & D & SD \\
\hline 25 & My institution offers compulsory courses in Research & & & & \\
\hline 26 & My institution usually organize seminars for students on Research & & & & \\
\hline 27 & I can carry out individual research by the end of my study & & & & \\
\hline 28 & $\begin{array}{l}\text { Most students' Research Projects in my institution are usually not } \\
\text { effectively supervised }\end{array}$ & & & & \\
\hline 29 & Students do not take seminars organizes by the institution seriously & & & & \\
\hline 30 & $\begin{array}{l}\text { Seminars organized by my institution are usually not effective enough to } \\
\text { help students gain adequate Research skills }\end{array}$ & & & & \\
\hline 31 & Few students usually attend seminars organized in my school & & & & \\
\hline 32 & $\begin{array}{l}\text { Based on my Research skills I will be able to train other students on how } \\
\text { to do good research at the end of my study }\end{array}$ & & & & \\
\hline
\end{tabular}

Section F: Poverty Alleviation, and Strengthening of National Unity and Consolidation of Democracy

\begin{tabular}{|c|c|c|c|c|c|}
\hline $\mathrm{S} / \mathrm{N}$ & Opinion & SA & A & $\mathbf{D}$ & SD \\
\hline 1 & Entrepreneurship is compulsory course in my institution & & & & \\
\hline 2 & I can create a job for myself after graduation & & & & \\
\hline 3 & If I create a job I will employ people irrespective of their background(s) & & & & \\
\hline 4 & I have skills to manage both financial and human resources & & & & \\
\hline 5 & The protection of the minority is one of my priorities & & & & \\
\hline 6 & Am ready to offer voluntary services after graduation & & & & \\
\hline 7 & I do discrimination among my friends based on cultural diversity & & & & \\
\hline 8 & $\begin{array}{l}\text { My institution encourages the creations of students socio cultural } \\
\text { associations /clubs }\end{array}$ & & & & \\
\hline
\end{tabular}

\subsection{Interview Guide for Teachers}

The following questions are based on the relationship between the implementation of higher education objectives and the attainment of Cameroon's vision 2035. 


\section{Section A: Demographic Information}

Institution:

Gender:

a) Male

b) Female

Section B: Promotion of Ethics and National Consciousness

\begin{tabular}{|c|l|l|}
\hline S $\backslash \mathbf{N}$ & Questions & Opinion \\
\hline 1 & $\begin{array}{l}\text { Do you encourage the teaching of Ethics and National } \\
\text { Consciousness as a course in your institution? } \\
\text { If yes how? } \\
\text { If no why? }\end{array}$ & \\
\hline 2 & $\begin{array}{l}\text { What role do you play in improving on students } \\
\text { Ethics and National Consciousness in your } \\
\text { institution? } \\
\text { How has that affected students' behavior? }\end{array}$ & \\
\hline
\end{tabular}

Section C: The Promotion of Bilingualism

\begin{tabular}{|c|c|c|}
\hline $\mathbf{S} \backslash \mathbf{N}$ & Questions & Opinion \\
\hline 1 & $\begin{array}{l}\text { Are you bilingual? What role do you play in } \\
\text { encouraging Bilingualism in your institution? } \\
\text { How has this affected students' performance? }\end{array}$ & \\
\hline 2 & $\begin{array}{l}\text { In Which language do you teach students? Based on } \\
\text { your language of instruction Do you evaluate } \\
\text { students orally and written during exams? To what } \\
\text { extern has this affected students skills of being } \\
\text { Bilingual? }\end{array}$ & \\
\hline
\end{tabular}

Section D: Strengthening of Gender Equality

\begin{tabular}{|c|l|l|}
\hline $\mathbf{S} \backslash \mathbf{N}$ & Questions & Opinion \\
\hline 1 & $\begin{array}{l}\text { Do you treat male and female students equally? } \\
\text { If yes how? } \\
\text { If no why? }\end{array}$ & \\
\hline 2 & $\begin{array}{l}\text { Do male and female students have equal learning } \\
\text { opportunities in your institution? }\end{array}$ & $\begin{array}{l}\text { How has this affected students' performance? } \\
\text { How are you ensuring that female students are given } \\
\text { equal learning opportunities as male students? }\end{array}$ \\
\hline
\end{tabular}

Section E: Organizing the Training of Trainers and Researchers

\begin{tabular}{|c|l|l|}
\hline $\mathbf{S} \backslash \mathbf{N}$ & Questions & Opinion \\
\hline 1 & $\begin{array}{l}\text { Does your institution offer Research as a compulsory } \\
\text { course? } \\
\text { Does your institution organize seminars to trains } \\
\text { teachers and students on research skills? } \\
\text { If yes how often and has that affected students skills } \\
\text { of research? }\end{array}$ & \\
\hline
\end{tabular}



$2 \quad$ Do you think students from your institution can carry out individual research after graduation? Give reasons for your opinion.
Does students' performances in research courses reflect their individual skills of carrying out a research? Give reasons for your opinion

Section F: Poverty Alleviation, and Strengthening of National Unity and Consolidation of Democracy

\begin{tabular}{|c|l|l|}
\hline S/N & Question & Opinion \\
\hline 1 & $\begin{array}{l}\text { Does your institution offer Entrepreneurship as a } \\
\text { compulsory course? } \\
\text { How has this affected student entrepreneurial skills? }\end{array}$ & \\
\hline 2 & $\begin{array}{l}\text { Do you think graduates from your institution can } \\
\text { have skills to create jobs for themselves after } \\
\text { graduation? } \\
\text { Support your opinion }\end{array}$ & \\
\hline 3 & $\begin{array}{l}\text { Do you think students from your institution have } \\
\text { skills to manage both financial and human resources? } \\
\text { How is this manifesting? }\end{array}$ & \\
\hline 4 & $\begin{array}{l}\text { Do you think students from your institution will be } \\
\text { willing to offer voluntary servicers after graduation? } \\
\text { Support your opinion }\end{array}$ & \\
\hline 5 & $\begin{array}{l}\text { How do you manage students from diverse cultural } \\
\text { background? How has this influence their peer } \\
\text { relationship in and out of the classroom? }\end{array}$ & \\
\hline 6 & $\begin{array}{l}\text { Does your institution encourage the creations of } \\
\text { students' socio cultural associations /clubs? } \\
\text { How has this affected unity and sense of democracy } \\
\text { among students? }\end{array}$ & \\
\hline
\end{tabular}

Thanks for your understanding and cooperation.

\section{Conclusion}

The questionnaire and an interview guide were appropriate instruments for the study "The Implementation of Higher Education Objectives and the Attainment of Cameroon's Vision 2035". The instruments where guided by research objective, research questions and literature review. It is important to mention that the interview guide was not strictly followed. That is to say, for probing purposes, the interview items were modified based on the situation of corresponding responses from the participants. The aforementioned instruments could serve as useful guide to the researchers working in the same or similar research project(s) at various context, to adapt or adopt the various items in this instruments when and wherever necessary. 


\title{
Conflict of Interest Statement
}

The author declare no conflicts of interests.

\begin{abstract}
About the Author
Awu Isaac Oben is a PhD scholar of Educational Leadership and Management at Southwest University, Chongqing, China. He holds a Bachelor's and Master's Degree of Education (B.Ed. and M.Ed.) in Curriculum Studies and Teaching from the University of Buea. His research interest includes; Higher Education, Educational Leadership and Management, STEM/STEAM Education-Integrated teaching, Curriculum and Instruction, Educational Policies, Teacher Education, Preservice and In-Service teacher preparation, School Improvement, English Language Teaching and learning, Teachers and Principals professional development, Research Policy, Policies to Improve Research.
\end{abstract}

\section{References}

Amin, M. E. (2005). Social Science Research: conception, methodology and analysis. Kampala: Makerere University.

Amin, M. E. and Fonkeng, E. G. (2008). Gender and the Demand for Primary Education in Cameroon. In V. Demos and M.T Segal (Eds), Social Change For Women and Children. Stanford: JAI Press.

Amin, M. E. (2002). Six factors of course and teaching evaluation in a bilingual university in central Africa. Assessment \& Evaluation in Higher Education 27,(3), 281-291.

Cameroon (1995). Final Report on the National Forum on Education Yaoundé, Ministry of National Education.

Cameroon schools. Limbe: Design House.

Cameroon (2001). Law No. 005 of 16 April 2001 to Guide Higher Education.

Darling, H. L. (1992). Teacher quality and students achievement: A review of state policy Evidence. Stanford University press

Design house Limbe, press print ltd, Limbe.

Doh, B. T. S. (2015). Evaluating the Strategic Objectives of Cameroonian Higher Education: An application of the Balanced Scorecard. JUVENES PRINT - Suomen Yliopistopaino Oy, Turku. https://www.researchgate.net/publication/279040912

Doh, P. S. (2007). Harmonization Challenges in Higher Education: Case of the French and British Bicultural System in Cameroon. Published Master's Thesis, University of Tampere, Finland. Available at: http://tutkielmat.uta.fi

Doh, P. S. (2008). Global Integration Policies Versus Institutional Dynamics of Higher Education. In Sarah \& Chalier, (eds.), The Implications of Competition for the Future of European Higher Education. European Education, vol. 40, pp. 78-97. 
Doh, P. S. (2012). The Responses of the Higher Education Sector in the Poverty Reduction Strategies in Africa: the Case of Cameroon. Doctoral Dissertation, Acta Universitatis Tamperensis 1755, Tampere University Press, Tampere.

Echu, G. (2005). The immersion experience in Anglophone Primary Schools in Cameroon. ISB4. In Proceedings of the 4th International Symposium on Bilingualism, ed. J. Cohen, K .T. McAlister, K. Rolstad and J. MacSwan, 643-55. Somerville, MA: Cascadilla Press.

Education to an undergraduate interdisciplinary studies degree program. The Journal of Continuing Higher Education. Vol59, 161-166.

Eid, F. H. (2014). Research, higher education and the quality of teaching: Inquiry in a Japanese academic context Higher Education Council, Kingdom of Bahrain. Research in Higher Education Journal Vol. 24

Elad, G. M. (1982). Schooling and National Integration in Cameroon. Thesis submitted in fulfilment of the requirements for the degree of Doctor of Philosophy in the Institute of Education. University of London.

Endeley, M. N. (2014). Teaching practice in Cameroon: The effectiveness of the University of Buea model and implications for quality. Australian Journal of Teacher Education, 39 (11). http://dx.doi.org/10.14221/ajte.2014v39n11.9

Fongwe, N. S. (2010). The Contribution of Higher Education to Regional Socio economic Development: The University of Buea, Cameroon, as a Growth Pole. A thesis submitted to University of the Western Cape

Fonkeng, G. E. (2007). The History of Education in Cameroon, 1884-2004. The Edwin Mellen Press, Lewiston.

Gagne, R. W. (1967). Curriculum research and the pro- motion of learning. In R. W. Tyler, R. M. Gagne, \& M. Scriven (Eds.), Perspectives of curricular evaluation. Chicago: Rand McNally.

Gelaneh, B. J. (2012). The Role of Civics and Ethical Education in the Development of Students' behavior: The Case of Kokebe Tsibiha Secondary and Preparatory school. A Thesis Submitted to Institute of Educational Research. Addis Ababa University. Addis Ababa, Ethiopia

GESP (2009). Growth and Employment Strategy Paper (2009): Reference work for government action over the Period 2010-2020 New York: MCG.RAW. Hill, Inc.

Glickman, C. D. (1985). Supervision of instruction: A developmental approach. USA: Allyn Bacon, Inc

Growth and Employment Strategy Paper (2009). Reference work for government action over the Period 2010-2020New York: MCG.RAW. Hill, Inc.

Harbison, F., \& Meyer, A. (1964). Education Manpower and Economic Growth: New York: Mac Growhill Book Company.

Harper, L \& Ross, J. (2011). An application of knowledge theories of adult

Henry, L. T. (2002). Introduction to sociology. Framingham state higher education university of Toronto press, pg 34-6. 
Kellner, M. G. and Douglas, D. (1989). Critical theory, Marxism and Modernity. Oxford printing.

Konings, P. (2004). Trade union activism among university teachers during Cameroons political liberalism. Nordic Journal of African Studies. Vol13 (3) P 289-301.

Kornblum, W. (1991). Sociology in a changing world. City university of New York, graduate school and University center. $2^{\text {nd }}$ edition.

Krejcie R. V. and Morgan D. W. (1970). Determining Sample Size for Research Activities, Educational and Psychological Measurement, 30,608, Sage Publications.

Mbiko, S. A. (1990). A Handbook on Research Methods. Etukokwu publishers (NIG) Ltd: Onisha Nigeria

Mbua, F. N. (2003). Educational administration: Theory and practice. Limbe; Design House.

Mbua, F. N. (2003). Educational planning: Issues and perspectives. Limbe: Design House.

Meek, A. (1993). On setting the Highest Standards: A conversation with Ralph Tyler. Educational Leadership, 50, 83-86.

MENESUP (2001). Law № 005/004 of $14^{\text {th }}$ April to Guide Higher Education in Cameroon. MINEDUC (1995). The National Education Forum (Yaoundé: MINEDUC).

MINEDUC (1998). Law No. 98/004 of 14 April to Lay Down Guidelines for Education in Cameroon (Yaoundé: Presidency of the Republic).

MINEPAT (2009). Growth and Employment Strategy Paper: Reference work for Government Action over the Period 2010-2020.

MINESUP (2001). Law No. 005 of 16 April 2001 to Guide Higher Education, Cameroon

MINJEF, (2016) Directories on Higher Institutes of Learning in the South West Region of Cameroon. Regional Delegation for Youths Affairs and Civic Education South West. P.O Box 007 Buea

Ndongko, T. M., \& Tambo, L. I. (2000). Educational development in Cameroon 1961- 1999 issues and perspectives. United State of America: Modison Wisdom Publishers Ltd.

Ndongko, T. M. (1989). A Handbook on Secondary School Administration. Ibadan: Heinemann Educational Books.

Ngwane, G. M. (2009). Vision 2035: Rebranding Cameroon. Retrieved, November 2015, from https://cameroonpostline.com/cameroun-vision-2035-rebranding-cameroon

Nsamenang, A. B. and Tchombe, T. M. (2011). Hand Book of Africa Educational Theories and Practices. A Generative Teacher Education Curriculum. Yaoundé, Cameroon press Universitaries D' Afrique.

Nsamenang, A. B. (2007). The Teaching Learning Transaction. T-junction, Bamenda, Anoh's printing service.

Ojong, T. T. (2008). Philosophical and historical foundations of education in Cameroon 18441960. Limbe: Design House.

Peters, R. S. (1964). Ethics and Education, London University Press.

Plessis, T. D. (2006). From Monolingual to Bilingual Higher Education: The Repositioning of Historically Afrikaans-Medium Universities in South Africa. Language Policy (2006) 5: 87-113. Springer. DOI 10.1007/s10993-005-5627-5. 
Republic of Cameroon (1998). Law № 98/004 of $14^{\text {th }}$ April to laying down Guidelines for Education in Cameroon.

Sadker, R. M., \& Sadker, M. D. (1991). Teachers, school and society. (2nded). New York: Mc Graw Hill, Inc.

Shu, S. N. (1985). Land marks in Cameroon education 1884-1982 (1 ${ }^{\text {sted }}$ ). Limbe: Nooremac Press.

SUP INFOS. (2010b). A Bilingual Quarter Review of Higher Education in Cameroon. No. 14, MINESUP Yaoundé, Cameroon.

Tamajong, E. V., \& Fonkeng, E. G. (2008). Secondary school administration and principalship. Yaoundé: Press University d'Afrique.

Tambo, L. I. (2003). Cameroon National Education Policy since the 1995 Forum. Limbe: Design House.

Tambo, L. I. (2003). Principles and methods of teaching. Application in Cameroon Schools. Limbe: Design House.

Tambo, L. I. (2012). Principles and Methods of Teaching. Application in Cameroon Schools. Limbe: Design House.

Tchombe, M. S. T (2004). Psychological Parenters in Teaching. Yaoundé, Cameroon. Press Universitairesd' Afrique.

Tchombe, T. M. (1994). Growth and development of teacher education in Cameroon. In Ndongko, T. M. \& Tambo, L. I. (Eds.) Educational Development in Cameroon 19611999: Issues and Perspectives. Nkemnji Global Tech, Platteville

Tchombe, T. M. (2000). Access of Girls to Basic Education in Cameroon, UNESCO

Tchombe, T. M. (2001). Structural Reforms in Education in Cameroon. http://www.unifr.ch/ipg/ecodoc/conferences/DocuPDFConfInter/Tchombe.pdf

Torney-Purta, J. and Wilkenfeld, B. (2009). Paths to 21st Century Competencies Through Civic Education Classrooms, Chicago, IL: American Bar Association Division for Public Education.

UNESCO (1998). Higher Education in the Twenty-First Century: Vision and Action, Paris

UNESCO (2003). Report of the Working Group on the Teaching of Ethics. Paris, COMEST

UNESCO-CEPES (2000). The bilingual university - its origins, mission, and functioning. Report on an invitational seminar, UNESCO-CEPES, Bucharest, Romania, 15-19 March 2000.

United Nations (2015). Transforming Our World. The 2030 Agenda for Sustainable Development. Retrieved January 10.2016, from, https://www.un.org/sustainabledevelopment/development-agenda/

World Bank (2009). The East Asian Miracle New York: Oxford University Press.

Yeba, J. S. (2015). Socio-cultural factors affecting gender inequality in higher education: Journal of Educational Research in Africa. 


\section{Appendix 1: Letter of Introduction}

\section{UNIIVERSITTYY OIF BUEA}

P.O. Box 63

Buea, South West Region

CAMEROON

TEL: (237) $33322134 / 33322690 / 33322706$

FAX: (237) $33432508 / 33322272$

FACULTY OF EDUCATION

Dean: Professor André Mvesso

Vice Dean / Programmes and Academic Affairs: Dr Titanji Peter Fon

Vice Dean / Studies and Student Affairs: Dr. Endeley Margaret Nalova

Vice Dean / Research and Cooperation: Dr. Nnane Peter Ebontane

Faculty Officer: Dr. Egbe Andrew Enow

\section{REPUBLIC OF CAMEROON}

PEACE - WORK - FATHERLAND

Your Ref.:

TO WHOM IT MAY CONCERN

\section{LETTER OF INTRODUCTION}

The candidate Awu Isaac Oben (ED14P018) is a Masters student in the Department of Curriculum Studies and Teaching (CST) of the Faculty of Education in the University of Buea. $\mathrm{He}$ is currently carrying out a research for a thesis, as a requirement, for the award of an M.Ed degree in Curriculum Studies and Teaching. The topic for the study is "The Implementation of Higher Education Objectives and the Attainment of Cameroon's Vision 2035". A research of this nature may require your maximum assistance and collaboration. It is for this reason that we are introducing him to you.

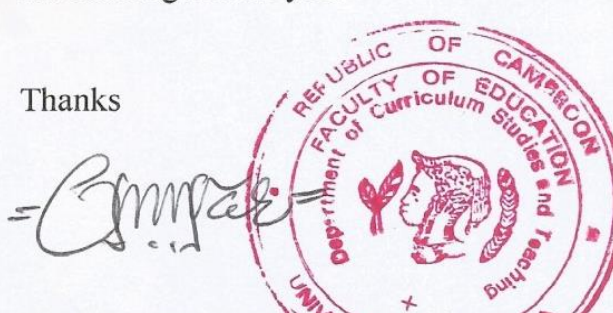

Dr. Agborbechem Perambi

Head of Department 2 FEV 2016 
RESEARCH INSTRUMENTS: A QUESTIONNAIRE AND AN INTERVIEW

GUIDE USED TO INVESTIGATE THE IMPLEMENTATION OF HIGHER EDUCATION OBJECTIVES AND THE ATTAINMENT OF CAMEROON'S VISION 2035

Appendix 2: Sample size(s) required for a given population sizes (N)
\begin{tabular}{|c|c|c|c|c|c|c|c|c|c|}
\hline $\mathbf{N}$ & $\mathbf{S}$ & $\mathbf{N}$ & $\mathbf{S}$ & $\mathbf{N}$ & $\mathbf{S}$ & $\mathbf{N}$ & $\mathbf{S}$ & $\mathbf{N}$ & S \\
\hline 10 & 10 & 100 & 80 & 280 & 162 & 800 & 260 & 2800 & 338 \\
\hline 15 & 14 & 110 & 86 & 290 & 165 & 850 & 256 & 3000 & 341 \\
\hline 20 & 19 & 120 & 92 & 300 & 169 & 900 & 269 & 3500 & 346 \\
\hline 25 & 24 & 130 & 97 & 320 & 175 & 950 & 274 & 4000 & 351 \\
\hline 30 & 28 & 140 & 103 & 340 & 181 & 1000 & 278 & 4500 & 354 \\
\hline 35 & 32 & 150 & 108 & 360 & 186 & 1100 & 285 & 5000 & 357 \\
\hline 40 & 36 & 160 & 113 & 380 & 191 & 1200 & 291 & 6000 & 361 \\
\hline 45 & 40 & 170 & 118 & 400 & 196 & 1300 & 297 & 7000 & 364 \\
\hline 50 & 44 & 180 & 123 & 420 & 201 & 1400 & 302 & 8000 & 367 \\
\hline 55 & 48 & 190 & 127 & 440 & 205 & 1500 & 306 & 9000 & 368 \\
\hline 60 & 52 & 200 & 132 & 460 & 210 & 1600 & 310 & 10000 & 370 \\
\hline 65 & 56 & 210 & 136 & 480 & 214 & 1700 & 313 & 15000 & 375 \\
\hline 70 & 59 & 220 & 140 & 500 & 217 & 1800 & 317 & 20000 & 377 \\
\hline 75 & 63 & 230 & 144 & 550 & 226 & 1900 & 320 & 30000 & 379 \\
\hline 80 & 66 & 240 & 148 & 600 & 234 & 2000 & 322 & 40000 & 380 \\
\hline 85 & 70 & 250 & 152 & 650 & 242 & 2200 & 327 & 50000 & 381 \\
\hline 90 & 73 & 260 & 155 & 700 & 248 & 2400 & 331 & 75000 & 382 \\
\hline 95 & 76 & 270 & 159 & 750 & 254 & 2600 & 335 & 100000 & 384 \\
\hline
\end{tabular}

Source: Krejcie. R.V and Morgan. D.W (1970) Determining Sample Size for Research Activities, Educational and Psychological Measurement, 30,608, Sage Publications. 

to copy, distribute, transmit or adapt the article content, providing a proper, prominent and unambiguous attribution to the authors in a manner that makes clear that the materials are being reused under permission of a Creative Commons License. Views, opinions and conclusions expressed in this research article are views, opinions and conclusions of the author(s). Open Access Publishing Group and European Journal of Education Studies shall not be responsible or answerable for any loss, damage or liability caused in relation to/arising out of conflicts of interest, copyright violations and inappropriate or inaccurate use of any kind content related or integrated into the research work. All the published works are meeting the Open Access Publishing requirements and can be freely accessed, shared, modified, distributed and used in educational, commercial and non-commercial purposes under a Creative Commons Attribution 4.0 International License (CC BY 4.0). 